\title{
Detection of schistosomiasis in an area directly affected by the São Francisco River large-scale water transposition project in the Northeast of Brazil
}

\author{
José Damião da Silva Filho ${ }^{[1],[2], ~ M a r t a ~ C r i s t h i a n y ~ C u n h a ~ P i n h e i r o ~}{ }^{[2],[3],}$ \\ Mariana Silva Sousa ${ }^{[2],[4]}$, Vivian da Silva Gomes ${ }^{[5]}$, Issis Maria Nogueira de Castro ${ }^{[1],[2],}$ \\ Alberto Novaes Ramos Júnior ${ }^{[3]}$ and Fernando Schemelzer de Moraes Bezerra ${ }^{[1],[2],[4]}$
}

\begin{abstract}
[1]. Programa de Pós-Graduação em Patologia, Faculdade de Medicina, Universidade Federal do Ceará, Fortaleza, CE, Brasil.
[2]. Laboratório de Parasitologia e Biologia de Moluscos, Faculdade de Farmácia, Odontologia e Enfermagem, Universidade Federal do Ceará, Fortaleza, CE, Brasil. [3]. Programa de Pós-Graduação em Saúde Coletiva, Faculdade de Medicina, Universidade Federal do Ceará, Fortaleza, CE, Brasil. [4]. Programa de Pós-Graduação em Ciências Médicas, Faculdade de Medicina, Universidade Federal do Ceará, Fortaleza, CE, Brasil. [5]. Núcleo de Controle de Vetores,

Secretaria de Saúde do Estado do Ceará, Fortaleza, CE, Brasil.
\end{abstract}

\begin{abstract}
Introduction: The development of the São Francisco River Integration Project [Projeto de Integração do Rio São Francisco (PISF)] in the State of Ceará, Brazil, has resulted in environmental and socioeconomic changes with potential risks to public health. We aimed to determine the presence of Schistosoma mansoni infections in schoolchildren (aged 7-14 years) and workers from the construction site in an area under the direct influence of the PISF in the municipality of Brejo Santo-CE, to aid in the prevention and control of schistosomiasis. Methods: We conducted a cross-sectional study using two S. mansoni-detection methods: detection of $S$. mansoni eggs by the Kato-Katz parasitological method in stool samples (assessed in triplicate for each sample) and $S$. mansoni circulating cathodic antigen by the point-of-care immunochromatographic rapid test (POC-CCA) in urine. Results: In general, the positivity rates for S. mansoni detection were $1.9 \%(2 / 106)$ among schoolchildren and $2.9 \%$ (4/138) among workers. No child had evidence of $S$. mansoni eggs in their stools; $1.9 \%$ tested positive by the POC-CCA method. Among workers, two (1.4\%) tested positive by the Kato-Katz test and three (2.2\%) by the POC-CCA test. If the POCCCA test results that were scored as traces were considered negative, then the positivity rates dropped to $0.9 \%$ and $0.7 \%$ for schoolchildren and workers, respectively. Conclusions: The active transmission of schistosomiasis in a region covered by the PISF was recognized, reinforcing the necessity to consolidate surveillance and control actions, as well as structural sanitation measures to reverse the social determinants of the disease.
\end{abstract}

Keywords: São Francisco River transposition. Diagnosis. Schistosomiasis. Schoolchildren. Workers. Epidemiology.

\section{INTRODUCTION}

Schistosomiasis is a persistent public health problem, with a global burden of 3 million disability-adjusted life years (DALYs), affecting more than 240 million people. It is estimated that nearly one billion people around the world are at risk of contracting the disease ${ }^{1-3}$.

In Brazil, an estimated 1.5 million people are infected, according to the National Prevalence Survey of Schistosomiasis and Geohelminthiases (2011-2014), with about 25 million individuals living in at-risk areas ${ }^{4}$. There are records of disease transmission in all regions of the country, affecting 18 states and

Corresponding author: Dr. Fernando Schemelzer de Moraes Bezerra. e-mail: bezerra@ufc.br

Received 28 July 2017

Accepted 5 October 2017 the Federal District 5 . Mortality due to schistosomiasis ranked second among those from neglected tropical diseases (NTDs) in the country during a 12-year period (2000-2011), with an annual average of over 700 deaths $^{6}$.

In Ceará, the Schistosomiasis Control Program (Programa de Controle da Esquistossomose - PCE) has been developed since 1977, currently reaching 71 (38.5\%) of 184 municipalities in the state. The disease is still routinely detected, mainly in municipalities of three regions of the State of Ceará: Cariri, Maciço do Baturité, and Serra da Ibiapaba. In the period from 2010 to 2015 , a total of 171,927 direct parasitological examinations were conducted; $0.3 \%(488 / 171,927)$ cases of infection with Schistosoma mansoni were detected, distributed in $26.7 \%(19 / 71)$ of the assessed municipalities ${ }^{7}$.

Multiple factors determine the occurrence of schistosomiasis and complicate its effective control in the country. From this 
perspective, poverty and precarious sanitary conditions, as well as migration of people, combined with the broad geographic distribution of intermediate hosts, favor the persistence and establishment of new outbreaks in Brazil ${ }^{5}$. In addition to these, modifications such as the construction of dams and power plants are introduced by humans in ecosystems and biomes, to contribute to economic needs, such as increase in energy demand, water supply, and food production. These water projects can create environments that are ecologically favorable to the introduction and dispersion of $S$. mansoni by establishing new breeding sites for snails, which are the intermediate hosts of this parasite, either naturally inhabiting the region or introduced from other endemic regions ${ }^{8,9}$.

The São Francisco River Integration Project [Projeto de Integração do Rio São Francisco (PISF)], is aimed at integrating the river with the Northeastern Hydrographic Basins, with the main objective of increasing water availability, and consequently, contributing to the socioeconomic development of the region. Further, this region has only $3 \%$ of the country's water availability and harbors $28 \%$ of the Brazilian population, and is constantly exposed to scarcity of rainfall and poor water distribution ${ }^{10}$.

This structuring project foresees the construction of more than $700 \mathrm{~km}$ of canals, distributed into two main axes: the Northern Axis that will bring water to the backlands of Pernambuco, Ceará, Paraíba, and Rio Grande do Norte; and the Eastern Axis, which will benefit part of the arid and rural regions of the States of Pernambuco and Paraíba. The project includes the recovery of 23 reservoirs, construction of 27 new reservoirs, in addition to 9 pumping stations, 4 tunnels, and 14 aqueducts. It is estimated that water security will be guaranteed to about 12 million inhabitants, in more than 390 cities, by $2025^{11,12}$.

Schistosoma mansoni infection has been reported along the São Francisco River, introducing high rates of infection and mortality, mainly in the States of Pernambuco, Alagoas, and Sergipe ${ }^{13,14}$. In addition, there are intermediate-host populations of schistosomiasis in all the states that constitute the region, with Biomphalaria glabrata and Biomphalaria straminea being mainly responsible for the transmission.

The present study starts from the intricate interactions between health, environment, and development, in the transmission-dynamics of schistosomiasis in areas under the influence of the São Francisco River water transposition. The objective of this study was to determine the presence of $S$. mansoni in schoolchildren, as well as in constructionsite workers from a municipality belonging to the area under the direct influence of the PISF in the State of Ceará, using parasitological and immunochromatographic diagnostic methodologies. It reinforces the relevance of planning and carrying out specific actions due to changes that may directly or indirectly affect the environment and the population's quality of life.

\section{METHODS}

\section{Study area and population}

A study was carried out in the municipality of Brejo Santo (Latitude: $7^{\circ} 29^{\prime} 36^{\prime \prime}$, Longitude: 38 59' 07"), located in the Southern Meso-region of the Ceará, located at $502 \mathrm{~km}$ from the
City of Fortaleza (capital), with an area of $661.96 \mathrm{~km}^{2}$ (Figure 1). The municipality has a resident population of 45,193 inhabitants as estimated in 2010, with a population density of over 68 inhabitants per square kilometer ${ }^{15}$.

Of the four municipalities in the state where PISF construction sites are installed, Brejo Santo is the municipality with the largest gross domestic product (BRL 11,260.12 in $2014)^{16}$. Its economy is based mainly on construction industry and commerce. These characteristics make this area attractive for labor absorption. This situation has been a conditioning factor for the migratory flow of workers and, in recent years, Brejo Santo has absorbed the labor force of several municipalities of Ceará and other states. The Municipal Human Development Index for 2010 was 0.647 ; however, $59.7 \%$ of the households had adequate sanitary sewer facilities in that year ${ }^{17}$.

\section{Schoolchildren}

According to the 2010 Demographic Census on education, the number of children, aged 7-14 years, in Brejo Santo was 4,097 students, distributed across 37 municipal schools in urban and rural areas ${ }^{15}$. The overall prevalence of the disease in the State of Ceará was 5\% (extrapolated value), with a margin of error of 5\% and a 95\% confidence level, which gave rise to an initial estimated minimum sample of 72 students.

In order to select the schools, we used the Environmental Impact Report that defined a directly affected area as a $5 \mathrm{~km}$-wide strip on each side of the structures to be built in the PISF ${ }^{18}$. Thus, only one rural school in operation was identified in the study area, as the others had been destroyed by the transposition works. For better representation of schoolchildren, it was decided to additionally select a school in the urban zone. Thus, of the 149 eligible students, 128 agreed to participate in the study; their legal guardians signed the free and informed consent form and filled out a questionnaire with socioeconomic information. Of the 128 students, 106 (2.6\% of the total students in the city) effectively participated in the study, delivering urine and stool samples in adequate amounts, and of the required quality, for the examinations.

\section{Workers from the construction site}

Of the 500 workers allocated at the Brejo Santo site in the study period, $138(27.6 \%)$ were included after signing the consent form and delivering urine and stool samples in adequate amounts, and of the required quality, for the examinations. All this process was carried out with the participation of the Ceará State Public Health Secretariat, Brejo Santo Municipal Public Health Secretariat, a company involved in the PISF and the Federal University of Ceará.

\section{Collection and processing of biological samples in the field}

Participants received two plastic collectors, with instructions to collect stool and urine samples, and were asked to return the plastic collectors with the samples on the next day.

Three slides were prepared with each stool sample using the Kato-Katz method from the Helm-Test kit (Bio-Manguinhos/ Fiocruz, RJ, Brazil) ${ }^{19}$. A $5 \mathrm{~mL}$-aliquot of the urine sample was stored in adequately identified cryotubes for further analysis 


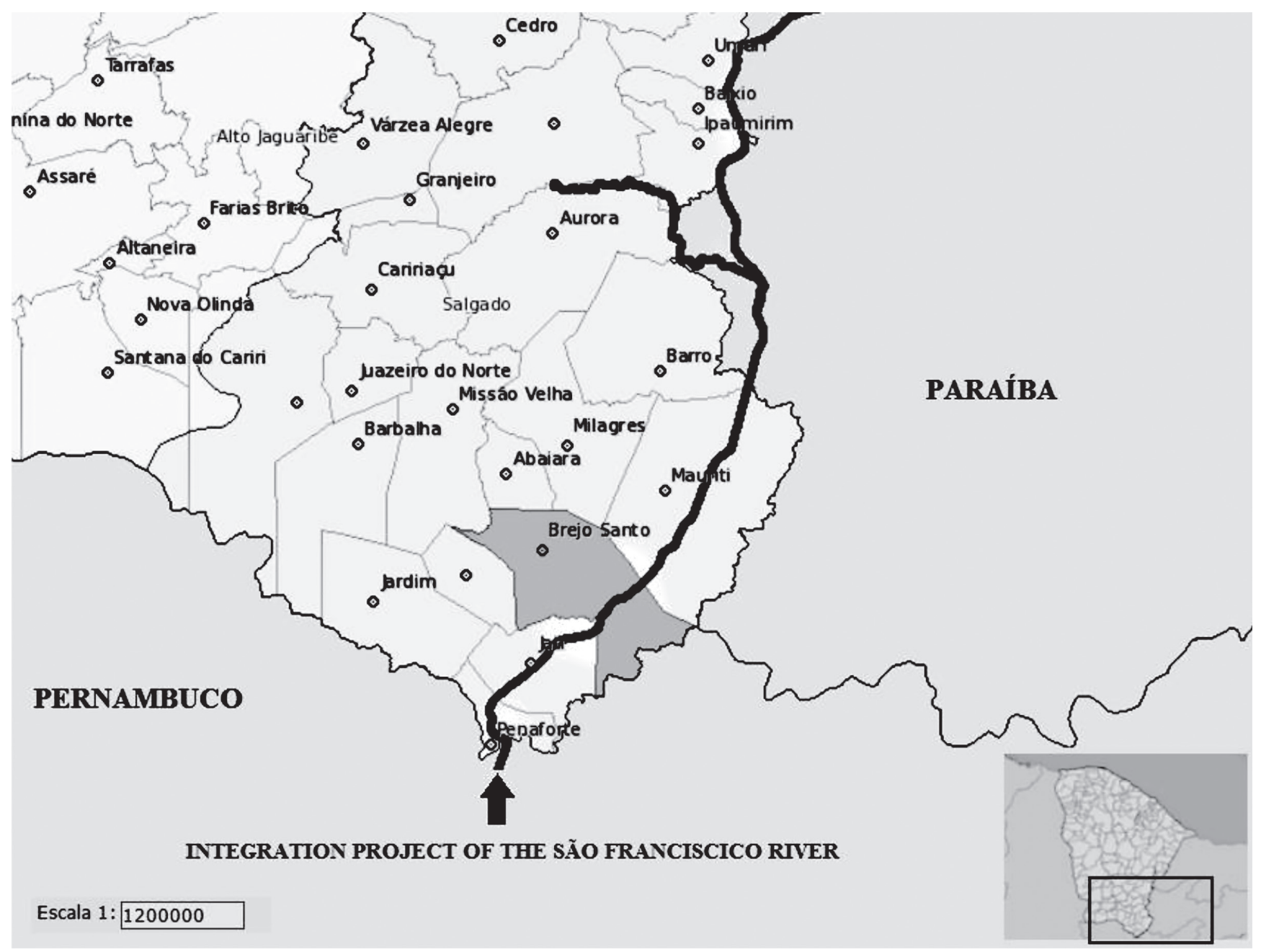

FIGURE 1 - Water transposition project circuit of the São Francisco River, with emphasis on the State of Ceará and the Brejo Santo municipality. Adapted: Secretariat of Water Resources of the State of Ceará.

using the point-of-care circulating cathode antigen (POC-CCA) method. The aliquots were preserved at $-20^{\circ} \mathrm{C}$ until they were transported to Fortaleza, to the Laboratory of Parasitology and Mollusk Biology located at the Federal University of Ceará, where they were stored at $-80^{\circ} \mathrm{C}$.

\section{Laboratory procedures}

For S. mansoni diagnosis, stool samples were examined for eggs with Kato-Katz stool smears prepared in triplicate. Infection intensity was calculated by determining the mean number of $S$. mansoni eggs found on the three slides and obtain number of eggs per gram (EPG) of stool (multiplying by 24).

The POC-CCA (Rapid Medical Diagnostics, Pretoria, South Africa) was performed using an experimental lot (a version prior to the currently marketed test), in which the buffer was withdrawn and 2 drops of urine were used. The test was performed at $24^{\circ} \mathrm{C}$ following the manufacturer's instructions. Briefly, two drops of the urine sample were transferred to the circular well of the test device and after 20 minutes the reading was performed. The valid tests (controlband visualized) were classified as positive, traces (weak test- band), or negative. Invalid tests (control-band undetectable) were repeated using the same urine sample.

\section{Statistical analysis}

Data were entered in Excel (Microsoft Corp., Redmond, WA) and analyzed using GraphPad Prism version 5.0 (GraphPad, San Diego, CA). The level of agreement between different diagnostic techniques was determined by the Kappa coefficient $(\kappa)$ with $95 \%$ confidence intervals $(95 \% \mathrm{CI})$ for each of the different approaches. According to Landis e Koch ${ }^{20}$, agreement was considered poor when $\kappa$ was $\leq 0.20$, weak when 0.21-0.40, moderate when 0.41-0.60, good when 0.61-0.80, and excellent when $\geq 0.81$.

\section{Ethical considerations}

The study protocol was approved by the Human Research Ethics Committee of the Federal University of Ceará (COMEPE $n^{\circ}$ 254/11 - Official no 14/16). All participants (schoolchildren and workers) and parents/legal guardians were informed of their rights under the Resolution 466/12 of the National Health Council and received the necessary explanations about the study. 


\section{RESULTS}

\section{Schoolchildren}

Of the 106 schoolchildren, $54.7 \%$ were females, $60.4 \%$ were from the municipality of Brejo Santo, and $69.8 \%$ had a monthly family income lower than 1 minimum-wage- [reference value: BRL 788.00 (USD 269.52) in 2015 ${ }^{21}$. Among the schoolchildren analyzed, none of the stool samples showed the presence of $S$. mansoni eggs. Using the POC-CCA test for the detection of S. mansoni antigen, one $(0.9 \%)$ child tested positive, one $(0.9 \%)$ showed trace amounts of the antigen, and the remaining 104 (98.1\%) were negative. Of the two positive cases, one came from the municipality of Brejo Santo (autochthonous), and the other one from the municipality of Santa Maria da Boa Vista, Pernambuco.

\section{Workers from the construction site}

All 138 workers were males, with a mean age of 40 years (range: 24-68 years). Using the Kato-Katz method, two (1.4\%) workers were tested positive; of the two, one worker (individual A) had the three positive slides (L1, L2, and L3), and in the other (individual B), only L3 was positive. The mean number of eggs was 5.33 for individual A ( $\mathrm{EPG}=128)$, indicating moderate parasite burden; and 0.3 for individual $\mathrm{B}(\mathrm{EPG}=8)$, suggesting a low parasitic burden. Of the urine samples tested with POCCCA, one $(0.7 \%)$ worker tested was positive, two $(1.5 \%)$ were scored as trace, and the remaining 135 (97.8\%) were negative. Overall, a total of four workers were tested positive either by the Kato-Katz and/or POC-CCA methods, resulting in a positivity rate of $2.9 \%$ (Figure 2).
The agreement between the parasitological technique and the POC-CCA test was weak, $(\kappa=0.39 ; 95 \% \mathrm{CI}=0-0.93)$, when the trace score was considered as positive. On the other hand, agreement was good, $(\kappa=0.66 ; 95 \% \mathrm{CI}=0.22-1.00)$, when the trace score was considered negative.

Further, the agreement between the diagnostic approaches, and combination of Kato-Katz ( 3 slides) and POC-CCA $(\mathrm{t}+$ ), is shown in Table 1. There were better levels of agreement between the diagnostic methods when Kato-Katz triplicates $(\kappa=0.66 ; 95 \% \mathrm{CI}=0.22-1.00)$ and POC-CCA $(\mathrm{t}+)(\kappa=0.85$; $95 \% \mathrm{CI}=0.57-1.00)$ were used.

\section{DISCUSSION}

The implementation of large ventures, such as PISF, invariably entails important environmental, economic, and sociocultural changes, interfering with the daily life of the populations and modifying their livelihoods, especially in relation to health conditions and quality of life. Thus, while the economic and social benefits that will be provided by the PISF are unquestionable, this large water-intervention project may also generate enormous environmental impacts that may have repercussions on the development and spread of diseases ${ }^{22}$. In addition, migratory movements of people generated by this project might not only contribute the spread of diseases in the migrants' areas-of-origin, but also to the increase of existing diseases in the recipient areas ${ }^{23-25}$. In this study, we report the presence of $S$. mansoni infection among schoolchildren (aged 7-14 years) and workers, at the construction site of PISF during the pre-transposition period, in the municipality of Brejo Santo in the State of Ceará. This is the first study

TABLE 1

Comparison between the Kato-Katz and POC-CCA methods in the detection of Schistosoma mansoni in samples obtained from workers at the construction site of PISF in Brejo Santo State of Ceará.

\begin{tabular}{|c|c|c|c|c|c|}
\hline & \multicolumn{5}{|c|}{ Kato-Katz (3 slides) + POC-CCA (t+) } \\
\hline Kato Katz positive (1 slide) & 1 & 0 & 1 & \multirow{2}{*}{0.39} & \multirow{2}{*}{$0-0.93$} \\
\hline Kato Katz negative & 3 & 134 & 137 & & \\
\hline Kato Katz positive (2 slides) & 1 & 0 & 1 & 0.39 & $0-0.93$ \\
\hline Kato Katz positive ( 3 slides) & 2 & 0 & 2 & \multirow{2}{*}{0.66} & \multirow{2}{*}{$0.22-1.00$} \\
\hline Kato Katz negative & 2 & 134 & 136 & & \\
\hline POC-CCA (t-) & 1 & 0 & 1 & 0.39 & $0-0.93$ \\
\hline
\end{tabular}

POC-CCA: Point-of-care circulating cathodic antigen; PISF: Programa de Integração do rio São Francisco; $\mathbf{t}-$ : trace-negative; $\mathbf{t}+$ : trace-positive; $\mathbf{C I}$ : confidence interval. 


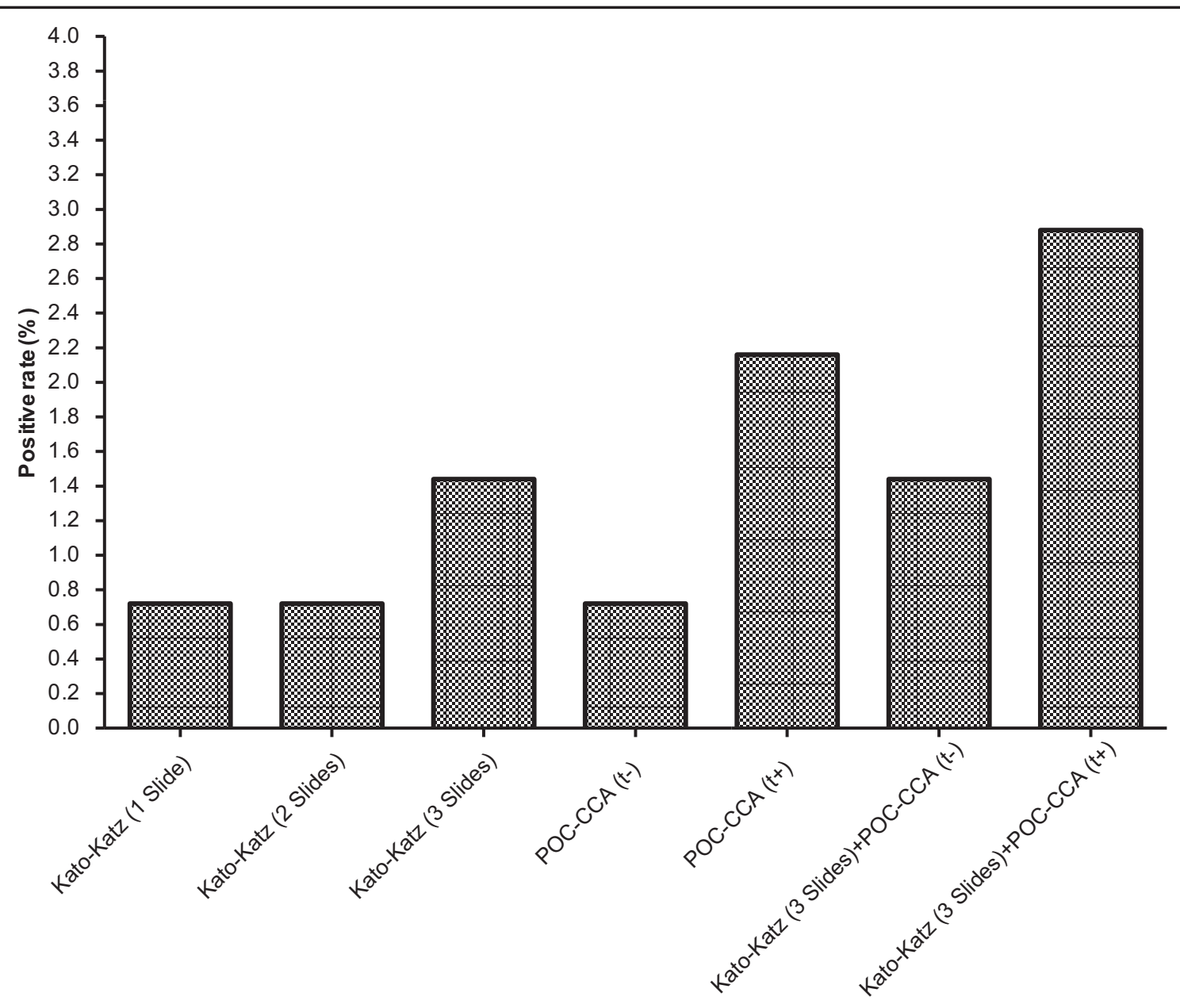

FIGURE 2 - Positivity for detection of Schistosomiasis mansoni in workers from the construction site of the São Francisco River integration project in the Brejo Santo, Ceará municipality, according to one-, two- and three-slide Kato-Katz analysis and the POC-CCA test. POC-CCA: point-of-care circulating cathodic antigen; $\mathbf{t}-$ : trace-negative; $\mathbf{t}+$ : trace-positive.

integrating the analysis of $S$. mansoni infection in a population of schoolchildren and workers at the PISF construction site to examine the active transmission dynamics of schistosomiasis in the region.

In Brazil, currently, the evaluation of the impact of water projects in relation to schistosomiasis has been limited to studies on the introduction of intermediate hosts ${ }^{8,24,26}$. Studies that demonstrate the presence of $S$. mansoni infections in resident and floating populations are scarce, especially in the construction phase of these projects. Of these, one study was carried out in the region of Rio Itabapoana, on the border of the States of Rio de Janeiro and Espírito Santo, where 13 workers were identified as coming from the endemic area, infected by $S$. mansoni, during the pre-admission screening for the construction of the Rosal Hydroelectric Plant ${ }^{27}$. Likewise, a study conducted by Favre and collaborators ${ }^{13}$ between April 2011 and June 2012 in 4,770 schoolchildren in municipalities of the four states covered by the PISF, identified six children $(0.13 \%)$ that were positive by the Kato-Katz method (using duplicate smears from single stool samples): one in Terra
Nova-PE, three in Sousa-PB, and two in Jucurutu-RN. These findings corroborate those of the present study; despite the low test-positivity rates found in these municipalities, the results indicate the presence of $S$. mansoni infections in this population, which in turn could serve as a sentinel population to monitor the progress of the control programs ${ }^{28}$.

In the past decades, PCE has been based mainly on active case search by means of coproscopic diagnosis, populationbased treatment programs in endemic areas, and surveillance and control of the intermediate hosts of S. mansoni (snails of the genus Biomphalaria). As a consequence of control actions and the relative improvement in general living conditions in endemic areas, the morbimortality burden of schistosomiasis has reduced, even though complete elimination of the disease has not been achieved $^{5}$. For a long time, schistosomiasis was considered a rural endemic disease. However, the disease has been increasing with expansion in urbanization. This increase in prevalence is due to migration of people, in addition to population growth to live in areas without basic sanitation, where there are natural water-courses that are natural breeding sites of the planorbid 
snails involved in the disease transmission cycle ${ }^{29,30}$.

The findings of the present study reinforces the notion that increase in the number of dams on a global scale has allowed the increase in the prevalence of schistosomiasis, as observed in the construction of the Aswan dam in Egypt ${ }^{31,32}$, Three Gorges Dam in China ${ }^{33,34}$, and the Kossou Dam in Cote d'Ivoire ${ }^{35}$. These observations demonstrate the importance of diagnosis in the phases prior to the project operation, in order to allow an early identification and treatment of positive cases, and subsequent prevention and monitoring of the onset of new outbreaks ${ }^{36}$.

Further, it is worth mentioning that the PISF construction sites have reached approximately 10,000 hired-professionals in the involved states ${ }^{37}$. The present study considers only the reality of one of the PISF construction sites in Ceará, probably underestimating the real extent of schistosomiasis in this population. There was an increase in the positivity rate of S. mansoni-detection, among workers using the Kato-Katz method, with the growth in the number of slides read per individual, corroborating findings from other reports that rise in the number of assessed slides results in an increase in the positivity rate and a consequent increase in the prevalence of S. mansoni $i^{38}$. In fact, the reading of only one or two slides, as routinely performed in schistosomiasis control programs ${ }^{39}$, would have detected only one positive individual in our study. As opposed to the World Health Organization (WHO) recommendation of assessing Kato-Katz smears of a single stool specimen in duplicate, our group sought to standardize the use of three smears per single stool-sample in order to improve the sensitivity of the method in this and other studies conducted by $\mathrm{us}^{38}$. Another alternative to improve the sensitivity of this method is to prepare and assess multiple smears of different samples from the same person; however, in epidemiological studies, repeated exams are economically unfeasible ${ }^{40,41}$.

The tests for the detection of circulating antigens have shown satisfactory results for the timely diagnosis, offering a promising complementary strategy to the traditional parasitological examination $^{42,43}$. In this study, the positivity rate determined by the POC-CCA test was higher than that determined by the Kato-Katz technique, even with three slides. Among students, the rate increased from $0 \%$ by the Kato-Katz method to $1.9 \%$ by the POC-CCA test. Likewise, among workers at the construction site, the rate of detection increased from $1.4 \%$ to $2.2 \%$ when the trace scores were considered positive. The concordance between the immunochromatographic and the parasitological technique was better when the trace score was considered as a negative result, as described elsewhere ${ }^{28}$.

The POC-CCA has some additional advantages over the traditional parasitological technique: the use urine as a biological sample, allows greater assent to the diagnostic procedure by patients who need to undergo the evaluation, as it is less embarrassing to them; besides being easy to perform and sensitive, it is applicable to epidemiological surveys of large populations. Recently, a study of a Brazilian population with low parasite burden in an endemic area showed that urine samples presenting traces of $S$. mansoni antigen were found in individuals with or without $S$. mansoni eggs in their feces. After concentration of urine sample ten times by lyophilization, the parasitological positive samples that were scored as trace by the previous POA-CCA test now became positive, but remained as trace in parasitological negative cases ${ }^{44}$. Thus, the interpretation of POC-CCA test results requires additional studies, since the distinction between positive- and trace-readings is subjective and requires standardization of the thresholds to be used for the visual interpretation of results. In our study, despite the differences between the two methodologies, the combination of the two proved to be an effective diagnostic strategy to obtain a better estimate of the $S$. mansoni-infection rate in this area that has historically exhibited low endemicity.

It is noteworthy that WHO has outlined a comprehensive plan to integrate access to water, sanitation, and hygiene services, with four other public-health interventions to accelerate overall progress in NTD control by 2020, in which schistosomiasis is one of the priorities ${ }^{45}$. Together with the Sustainable Development Objectives (ODS), strategic spaces are created in global and national agendas for the development of integrated control actions ${ }^{46}$.

Despite the low positivity rate found in the study area, the transmission dynamics of schistosomiasis persists in this region, and may be further influenced by the arrival of the waters of the São Francisco River. Investments are required for surveillance actions, especially with the use of more sensitive and adequate techniques, as well as systematic studies on the impact of the largest water-project under construction in Brazil, throughout the area of its influence, before, during, and after its construction.

\section{Acknowledgments}

The authors are grateful to the Central Laboratory of Public Health of Ceará State, the Health Secretariat of Ceará State, the Brejo Santo municipality and Serveng Group for the technical and logistic support. We also would like to acknowledge Neels van Rooyen from Rapid Medical Diagnostics and Santiago Nichollas from PAHO/WHO for the donation of POC-CCA kits.

\section{Financial support}

Health Unic System Research Program (Programa Pesquisa para o Sistema Único de Saúde - PPSUS) - Call 03/2012.

\section{Conflict of interest}

The authors declare that there is no conflict of interest.

\section{REFERENCES}

1. World Health Organization (WHO). Schistosomiasis - Situation and trends [Internet]. Geneva: WHO; 2016 - [updated 2016 Nov 11; cited 2017 June 26]. Available from: http://www.who.int/gho/neglected diseases/schistosomiasis/en/

2. Murray CJ, Barber RM, Foreman KJ, Abbasoglu Ozgoren A, AbdAllah F, Abera SF, et al. Global, regional, and national disabilityadjusted life years (DALYs) for 306 diseases and injuries and healthy life expectancy (HALE) for 188 countries, 1990-2013: quantifying the epidemiological transition. Lancet. 2015;386(10009):2145-91. 
3. Hotez PJ, Fujiwara RT. Brazil's neglected tropical diseases: an overview and a report card. Microbes Infect. 2014;16(8):601-6.

4. Katz N, Rocha RS, Simões Barbosa C, Bezerra FSM, Coelho PMZ, Carvalho OS, et al. National survey on Schistosomiasis mansoni and Geohelminths in Brazil (2011-2014). XIII International Congress of Parasitology - ICOPA; Aug 10-15; Mexico City, Mexico. 2014.

5. Ministério da Saúde. Vigilância da Esquistossomose Mansoni. Diretrizes Técnicas. Brasília: Secretaria de Vigilância em Saúde; 2014. p. 1-144. Acessado em 20 de outubro. Disponível em: http:// bvsms.saude.gov.br/bvs/publicacoes/vigilancia_esquistossome_ mansoni_diretrizes_tecnicas.pdf. 2016

6. Martins-Melo FR, Ramos Jr AN, Alencar CH, Heukelbach J. Trends and spatial patterns of mortality related to neglected tropical diseases in Brazil. Parasite Epidemiol Control. 2016;1(2):56-65.

7. Secretaria da Saúde do Estado do Ceará. Boletim Epidemiológico de Esquistossomose. Fortaleza: Núcleo de Vigilância Epidemiológica; 2016. 5p. Acessado em 13 de outubro, 2016. Disponível em: http:// www.saude.ce.gov.br/index.php/boletins.

8. Rezende HR, Sessa PA, Ferreira AL, Santos CB, Leite GR, Falqueto A. Efeitos da implantação da Usina Hidrelétrica de Rosal, Rio Itabapoana, Estados do Espírito Santo e Rio de Janeiro, sobre anofelinos, planorbídeos e flebotomíneos. Rev Soc Bras Med Trop. 2009;42(2):160-4.

9. Diakité NR, Winkler MS, Coulibaly JT, Guindo-Coulibaly N, Utzinger J, N'Goran EK. Dynamics of freshwater snails and Schistosoma infection prevalence in schoolchildren during the construction and operation of a multipurpose dam in central Côte d'Ivoire. Infect Dis Poverty. 2017;6(1):93.

10. Ministério da Integração Nacional. Projeto de Integração do Rio São Francisco. Brasília: Assessoria de Comunicação Social; 2014. p. 1-8. Acessado em 24 de agosto de 2015. Disponível em: http:// www.mi.gov.br/c/document_library/get_file?uuid=261be082-5ac543b7-8e8b-59bb61b1b108\&groupId=2054191.

11. Ministério da Integração Nacional. Projeto de Integração do Rio São Francisco com Bacias Hidrográficas do Nordeste Setentrional Relatório de Impacto Ambiental (RIMA). Brasília: MIN; 2004. 136p. Acessado em 25 de novembro de 2016. Disponível em: http://www. mi.gov.br/documents/10157/3678963/Rima+-+Relat\%C3\%B3rio+de +Impacto+Ambiental.pdf/4324863d-cbff-4522-9bd0-eab9d34b8fe2.

12. Castro CN. Transposição do Rio São Francisco: Análise de Oportunidade do Projeto. Rio de Janeiro: Instituto de Pesquisas Econômicas Aplicadas (IPEA); 2011. 60p.

13. Favre TC, Fernandez MA, Beck LCNH, Guimarães RJPS, Pieri OS, Thiengo SAC. Assessment of schistosomiasis in the semi-arid Northeast region of Brazil: the São Francisco River large-scale water transposition project. Rev Soc Bras Med Trop. 2016;49(2):252-7.

14. Martins-Melo FR, Pinheiro $\mathrm{MCC}$, Ramos AN, Alencar $\mathrm{CH}$, Bezerra FSM, Heukelbach J. Spatiotemporal Patterns of Schistosomiasis-Related Deaths, Brazil, 2000-2011. Emerg Infect Dis. 2015;21(10):1820-3.

15. Instituto Brasileiro de Geografia e Estatística (IBGE). Pesquisa Nacional por Amostra de Domicílios. Síntese de Indicadores 2013. Rio de Janeiro: IBGE; 2016. 288p. Acessado em 28 de outubro, 2016. Disponível em: http://biblioteca.ibge.gov.br/visualizacao/ livros/liv94414.pdf

16. Instituto Brasileiro de Geografia e Estatística (IBGE). Cidades Brejo Santo-CE. Rio de Janeiro: IBGE; 2017. Acessado em 15 de janeiro, 2017. Disponível em: https://cidades.ibge.gov.br/brasil/ce/ brejo-santo/panorama

17. Programa das Nações Unidas para o Desenvolvimento (PNUD). Atlas do Desenvolvimento Humano no Brasil 2013. Rio de Janeiro:
PNUD, IPEA, Fundação João Pinheiro; 2013. Acessado em 28 de outubro, 2016. Disponível em: http://www.atlasbrasil.org. br/2013/o_atlas/idhm

18. Ministério da Integração Nacional. Projeto de Integração do Rio São Francisco com Bacias Hidrográficas do Nordeste Setentrional - Consolidação dos Estudos Ambientais. Brasília: Consórcio Ecology Brasil, Agrar Consultoria e Estudos Técnicos, JP Meio Ambiente; 2004. 120p. Acessado em 25 de novembro, 2016. Disponível em: http://licenciamento.ibama.gov.br/Recursos\%20 Hidricos/Integracao\%20Sao\%20Francisco/EIA/Textos/EIA\%20 Consolidado\%20Item\%2011\%20An\%E1lise\%20de\%20Impactos. pdf.

19. Katz N, Chaves A, Pellegrino J. A simple device for quantitative stool thick smear technique in schistosomiasis mansoni. Rev Inst Med Trop Sao Paulo. 1972;14(6):397-400.

20. Landis JR, Koch GG. The measurement of observer agreement for categorical data. Biometrics. 1977;33(1):159-74.

21. Brasil. Decreto n. 8.381, de 29 de dezembro de 2014. Dispõe sobre o Valor do salário mínimo e a sua política de valorização de longo prazo de 2014. Brasília: Diário Oficial da União (30.12.2014). Acessado em 10 de março, 2016. Disponível em: http://www. normaslegais.com.br/legislacao/Decreto-8381-2014.htm.

22. Tubaki RM, Menezes RM, Cardoso JR RP, Bergo ES. Studies on entomological monitoring: mosquito species frequency in riverine habitats of the Igarapava Dam, Southern Region, Brazil. Rev Inst Med Trop São Paulo. 2004;46(4):223-9.

23. Barbosa CS, Araújo KC, Sevilla MAA, Melo F, Gomes ECDS, Souza-Santos R. Current epidemiological status of schistosomiasis in the state of Pernambuco, Brazil. Mem Inst Oswaldo Cruz. 2010;105(4):549-54.

24. Thiengo SC, Santos SB, Fernandez AF. Malacofauna límnica da área de influência da Usina Hidrelétrica de Serra da Mesa, GO, Brasil. I. Estudo qualitativo. Rev Bras Zool. 2005;22(4):867-74.

25. World Health Organization (WHO). Report of the WHO informal consultation on schistosomiasis in low transmission areas: control strategies and criteria for elimination. Geneva: WHO; 2001, 51p. Available from: http://apps.who.int/iris/bitstream/10665/66904/1/ WHO_CDS_CPE_SIP_2001.1.pdf?ua=1

26. Fernandez MA, de Mattos AC, da Silva EF, Santos SB, Thiengo SC. A malacological survey in the Manso Power Plant, State of Mato Grosso, Brazil: new records of freshwater snails, including transmitters of schistosomiasis and exotic species. Rev Soc Bras Med Trop. 2014;47(4):498-506.

27. Companhia de Eletricidade do Rio de Janeiro (CERJ). Relatório de Impacto Ambiental. Aproveitamento Hidrelétrico do Rio Itabapoana, Usina Hidrelétrica de Rosal, Rio de Janeiro/Espírito Santo ( ${ }^{\circ}$ 504.03). Rio de Janeiro: CERJ. 1992. Acessado em 15 de junho, 2017. Disponível em: http://www.hidroweb.ana.gov.br/doc/ BHASLeste/rj.doc.

28. Coulibaly JT, N'Gbesso YK, Knopp S, N'Guessan NA, Silué KD, van Dam GJ, et al. Accuracy of urine circulating cathodic antigen test for the diagnosis of Schistosoma mansoni in preschoolaged children before and after treatment. PLoS Negl Trop Dis. 2013;7(3):e2109.

29. Kloos H, Correa-Oliveira R, dos Reis DC, Rodrigues EW, Monteiro LAS, Gazzinelli A. The role of population movement in the epidemiology and control of schistosomiasis in Brazil: a preliminary typology of population movement. Mem Inst Oswaldo Cruz. 2010;105(4):578-86.

30. Guimarães ICS, Tavares-Neto J. Transmissão urbana de esquistossomose em crianças de um bairro de Salvador, Bahia. Rev Soc Bras Med Trop. 2006;39(5):451-5. 
31. Barakat RMR. Epidemiology of schistosomiasis in Egypt: travel through time: Review. J Adv Res. 2013;4(5):425-32.

32. Steinmann P, Keiser J, Bos R, Tanner M, Utzinger J. Schistosomiasis and water resources development: systematic review, meta-analysis, and estimates of people at risk. Lancet Infect Dis. 2006;6(7):411-25.

33. Zhu HM, Xiang S, Yang K, Wu XH, Zhou XN. Three Gorges Dam and its impact on the potential transmission of schistosomiasis in regions along the Yangtze River. Ecohealth. 2008;5(2):137-48.

34. McManus DP, Gray DJ, Li Y, Feng Z, Williams GM, Stewart D, et al. Schistosomiasis in the People's Republic of China: the Era of the Three Gorges Dam. Clin Microbiol Rev. 2010;23(2):442-66.

35. N'Goran EK, Diabate S, Utzinger J, Sellin B. Changes in human schistosomiasis levels after the construction of two large hydroelectric dams in central Côte d'Ivoire. Bull World Health Organ. 1997;75(6):541-5.

36. Berhe N, Medhin G, Erko B, Smith T, Gedamu S, Bereded D, et al. Variations in helminth faecal egg counts in Kato-Katz thick smears and their implications in assessing infection status with Schistosoma mansoni. Acta Trop. 2004;92(3):205-12.

37. Ministério do Planejamento (MP). Integração do São Francisco está em fase final com $86,3 \%$ das obras concluídas. Brasília: Plano de Aceleração do Crescimento; 2016. Acessado em 15 de outubro, 2016. Disponível em: http://www.pac.gov.br/noticia/47f0d553

38. Pinheiro MCC, Carneiro TR, Hanemann ALDP, Oliveira SMD, Bezerra FSM. The combination of three faecal parasitological methods to improve the diagnosis of schistosomiasis mansoni in a low endemic setting in the state of Ceará, Brazil. Mem Inst Oswaldo Cruz. 2012;107(7):873-6.

39. World Health Organization (WHO). Prevention and control of schistosomiasis and soil-transmitted helminthiasis. Report No. 912.
Geneva: WHO; 2002. Available from: http://whqlibdoc.who.int/ trs/ WHO TRS 912.pdf

40. Enk MJ, Lustosa Lima AC, Drummond SC, Schall VT, Coelho PMZ. The impact of the number of stool samples on the prevalence, the infection intensity and the distribution of the infection with Schistosoma mansoni among a population in an area of low transmission. Acta Trop. 2008;108(2-3):222-8.

41. Utzinger J, N'Goran EK, N'Dri A, Lengeler C, Tanner M. Efficacy of praziquantel against Schistosoma mansoni with particular consideration for intensity of infection. Trop Med Int Health. 2000;5(11):771-8.

42. Siqueira LMV, Couto FFB, Taboada D, Oliveira AA, Carneiro NFF, Oliveira E, et al. Performance of POC-CCA ${ }^{\circledR}$ in diagnosis of schistosomiasis mansoni in individuals with low parasite burden. Rev Soc Bras Med Trop. 2016;49(3):341-7.

43. Colley DG, Binder S, Campbell C, King CH, Tchuem Tchuentè LA, N'Goran EK, et al. A five-country evaluation of a Point-ofCare circulating cathodic antigen urine assay for the prevalence of Schistosoma mansoni. Am J Trop Med Hyg. 2013;88(3):426-32.

44. Coelho PMZ, Siqueira LMV, Grenfell RFQ, Almeida NBF, Katz N, Almeida A, et al. Improvement of POC-CCA Interpretation by Using Lyophilization of Urine from Patients with Schistosoma mansoni Low Worm Burden: Towards an Elimination of Doubts about the Concept of Trace. PLoS Negl Trop Dis. 2016;10(6): e0004778.

45. World Health Organization. (WHO). Schistosomiasis: progress report 2001-2011, strategic plan 2012-2020. Geneva: WHO; 2013. 74p. Available from: http://www.who.int/iris/handle/10665/78074

46. United Nations Organization (ONU). Transforming our World: The 2030 Agenda for Sustainable Development. Ney Work: ONU; 2015. 41p. Available from: https://sustainabledevelopment.un.org/ post2015/transformingourworld/publication 